\begin{tabular}{|c|c|c|}
\hline & International Journal of Current Research in & \\
\hline & Biosciences and Plant Biology & $\frac{1}{2}+0$ \\
\hline PUBL & $\begin{array}{c}\text { ISSN: 2349-8080 (Online) • Volume } 3 \bullet \text { Number } 4 \\
\text { Journal homepage: www.ijcrbp.com }\end{array}$ & \\
\hline
\end{tabular}

\title{
Influence of Plant Densities and Age of Seedlings on Dry Matter Partitioning and Grain Yield Potential of Transplanted Rice (Oryza sativa L.)
}

\author{
G. Vijayalaxmi, G. Sreenivas, P. Leela Rani* and T. Ram Prakash \\ Department of Agronomy, College of Agriculture, Professor Jayashankar Telangana Agricultural University, Rajendranagar, \\ Hyderabad-50o 030, Telangana State, India \\ *Corresponding author.
}

\begin{abstract}
A bstract
An experiment was carried out during kharif, 2013 at College Farm, Rajendranagar, Hyderabad. with three plant densities $\left(1\right.$ seedling hill ${ }^{-1}, 3$ seedlings hill ${ }^{-1}, 5$ seedlings hill $\left.^{-1}\right)$ as factor one and four age of seedlings (15 days old seedlings, 25 days old seedlings, 35 days old seedlings, 45 days old seedlings) as factor two in randomized block design, replicated thrice. Experimental results showed 5 seedlings hill ${ }^{-1}$ was found to be significant to get more productive tillers (288) and grain yield $\left(5817 \mathrm{~kg} \mathrm{ha}^{-1}\right)$ over 3 seedlings hill ${ }^{-1}$ and 1 seedling hill ${ }^{-1}$ due to more dry matter production $(348,793$ and $1296 \mathrm{~g} \mathrm{~m}^{-2}$ ) at panicle initiation, heading and physiological maturity stages and dry matter partitioning as stem, leaf and grain $\left(300,242\right.$ and $\left.754 \mathrm{~g} \mathrm{~m}^{-2}\right)$ at physiological maturity stage respectively over 3 seedlings hill ${ }^{-1}$ and 1 seedling hill ${ }^{-1}$. Among different age of seedlings significantly more productive tillers and grain yield was obtained with 25 days old seedlings over 15,30 and 45 days old seedlings with more dry matter at panicle initiation, heading and physiological maturity stages and dry matter partitioning as stem, leaf and grain $\left(330,261\right.$ and $\left.824 \mathrm{~g} \mathrm{~m}^{-2}\right)$ at physiological maturity.
\end{abstract}

\section{Article Info}

Accepted: 19 March 2016

Available Online: 06 April 2016

Ke ywords

Age of seedlings

Dry matter partitioning

Grain yield

Number of seedlings

Oryza sativa

\section{Introduction}

In India, rice is grown in an area of 45.5 million ha, with a productivity of $2.13 \mathrm{t} \mathrm{ha}^{-1}$. India needs to produce 120 million tons by 2025 as against 104.32 million tons to feed its one and a half billion plus population by then (RKMP, 2013). Rice is the most important staple food crop in Andhra Pradesh followed by maize. It is grown in all agro ecological zones from North coastal zone to high altitude and tribal zone. In Andhra Pradesh, rice is mostly cultivated as irrigated eco-system under canals (52\%), tube wells (19.31), tanks (16.2\%), other wells $(8.8 \%)$ and other sources of water $(3.7 \%)$, with an average rice productivity of $3333 \mathrm{~kg} \mathrm{ha}^{-1}$ compared to $2001 \mathrm{~kg} \mathrm{ha}^{-1}$ (India) and world average of $4112 \mathrm{~kg} \mathrm{ha}^{-1}$
(RKMP, 2013). Although the productivity of rice is higher than India but it is less than the world. The yield gap is due to the late onset of monsoon, uneven distribution of rainfall and late release of water into the canals. This lead to use of over aged seedlings from the nursery and transplanting of more number of seedlings hill $^{-1}$. So it is necessary to use properly managed seedbeds with adequate nutrition and optimum seedling densities at appropriate age are important factors to get vigorous plant stands after transplanting. The productivity of cereals depends not only on the accumulation of dry matter, but also on effective partitioning of the dry matter to economically important plant parts. The yield of rice is the result of various processes, including canopy photosynthesis, conversion 
of assimilates to biomass and partitioning of assimilates to grains (harvest index) (Jeng et al., 2006). So the optimum plant density plays an important role in determining the accumulation of biomass. Therefore, an experiment was carried out with an objective to study the effect of plant density and age of seedlings for enhancing partitioning of DM to get maximum grain yield.

\section{Materials and methods}

The experiment was carried out during kharif, 2013 at college farm, Acharya N G Ranga Agricultural university, Rajendranagar, Hyderabad situated at an altitude of $542.3 \mathrm{~m}$ above mean sea level at $17^{\circ} 19^{\prime} \mathrm{N}$ latitude and $78^{\circ} 23^{\prime}$ E longitude. It is in the Southern Telangana agro-climatic zone of Andhra Pradesh. According to Troll's climatic classification, it falls under semi-arid tropics (SAT). The soil of the experimental site was sandy loam in texture, alkaline in reaction, low in available nitrogen $\left(210 \mathrm{~kg} \mathrm{~N} \mathrm{ha}^{-1}\right)$, medium in phosphorus (14.14 kg P ha ${ }^{-1}$ ) and high in available potassium $\left(249.76 \mathrm{~kg} \mathrm{~K} \mathrm{ha}^{-1}\right)$. The experiment was laid out in randomized block design (factorial) with three plant densities $\left(1\right.$ seedling hill ${ }^{-1}, 3$ seedlings hill ${ }^{-1}$ and 5 seedlings hill $\left.{ }^{-1}\right)$ and four age of seedlings $(15,25$, 35 and 45 days old seedlings. Uniform fertilizer dose of $150 \mathrm{~kg} \mathrm{ha}^{-1} \mathrm{~N}, 60 \mathrm{~kg} \mathrm{ha}^{-1} \mathrm{P}$ and $4 \mathrm{~kg} \mathrm{ha}^{-1} \mathrm{~K}$ was applied in the form of urea, di ammonium phosphate and muriate of potash, respectively at the time of puddling. Nitrogen was applied in three equal splits (planting, 20 DAT and panicle primordial initiation). Other cultural operations and plant protection measures were followed as per the recommendations. During the crop period rainfall of $532.4 \mathrm{~mm}$ was received in 28 rainy days in 2013 as against the decennial average of $518.2 \mathrm{~mm}$ received in 34 rainy days, for the corresponding period. Plant samples of rice were collected for dry matter estimation at panicle initiation, heading and physiological maturity stages from different treatments. Data were collected on grain yield. Plants were threshed, grains were counted, weighed and the grain yield ha ${ }^{-1}$ was worked out.

\section{Results and discussion}

Significantly the highest dry matter $\mathrm{m}^{-2}$ was produced from 5 seedlings hill $^{-1}\left(\mathrm{~S}_{3}\right)$ at panicle initiation, heading and physiological maturity stages over 3 seedlings hill ${ }^{-1}$ $\left(\mathrm{S}_{2}\right)$ and 1 seedling hill ${ }^{-1}\left(\mathrm{~S}_{1}\right)$, which in turn recorded the lowest dry matter $\mathrm{m}^{-2}$ at panicle initiation, heading and physiological maturity stages (Table 1). This might be due to more number of leaves which occupied the same land area and consequently trapped more light and $\mathrm{CO}_{2}$ resulting in higher photosynthesis and producing more dry matter (Damodaran et al., 2012).

Accumulation of higher dry matter was observed with 25 days old seedlings $\left(D_{2}\right)$ at panicle initiation, heading and physiological maturity stages. However, it was significantly superior to $15\left(\mathrm{D}_{1}\right), 35\left(\mathrm{D}_{3}\right)$ and 45 days old seedlings $\left(\mathrm{D}_{4}\right)$, in turn $\mathrm{D}_{4}$ recorded the lowest dry matter accumulation at panicle initiation, heading and physiological maturity stages (Table 1 ). These results substantiate the findings of Thiyagarajan et al. (2002) who noticed that the younger seedlings produced more tillers subsequently more dry matter.

Table 1. Dry matter $\left(\mathrm{g} \mathrm{m}^{-2}\right)$ production of rice under varied plant densities and age of seedlings.

\begin{tabular}{|c|c|c|c|}
\hline Treatments & Panicle initiation & Heading & Physiological maturity \\
\hline \multicolumn{4}{|l|}{ Plant densities (S) } \\
\hline $\mathrm{S}_{1}\left(1\right.$ seedling hill $\left.{ }^{-1}\right)$ & $273^{\mathrm{c}}$ & $707^{\mathrm{c}}$ & $1177^{\mathrm{c}}$ \\
\hline $\mathrm{S}_{2}\left(3\right.$ seedlings hill $\left.{ }^{-1}\right)$ & $332^{\mathrm{b}}$ & $752^{\mathrm{b}}$ & $1231^{\mathrm{b}}$ \\
\hline$S_{3}\left(5\right.$ seedlings hill $\left.{ }^{-1}\right)$ & $348^{\mathrm{a}}$ & $793^{\mathrm{a}}$ & $1296^{\mathrm{a}}$ \\
\hline $\mathrm{SEm} \pm$ & 5.1 & 4.6 & 17.3 \\
\hline $\mathrm{CD}(p=0.05)$ & 15.0 & 13.5 & 50.9 \\
\hline \multicolumn{4}{|l|}{ Age of seedlings (D) } \\
\hline $\mathrm{D}_{1}$ (15 days old seedlings) & $325^{\mathrm{b}}$ & $794^{\mathrm{b}}$ & $1321^{\mathrm{b}}$ \\
\hline $\mathrm{D}_{2}$ (25 days old seedlings) & $354^{\mathrm{a}}$ & $823^{\mathrm{a}}$ & $1415^{\mathrm{a}}$ \\
\hline $\mathrm{D}_{3}$ (35 days old seedlings) & $307^{\mathrm{c}}$ & $768^{\mathrm{c}}$ & $1230^{\mathrm{c}}$ \\
\hline $\mathrm{D}_{4}$ (45 days old seedlings) & $284^{d}$ & $619^{d}$ & $974^{\mathrm{d}}$ \\
\hline SEm \pm & 5.9 & 5.3 & 20.0 \\
\hline $\mathrm{CD}(p=0.05)$ & 17.4 & 15.6 & 58.7 \\
\hline SEm \pm & 10.2 & 9.2 & 34.7 \\
\hline $\mathrm{CD}(p=0.05)$ & NS & NS & NS \\
\hline
\end{tabular}

Note: Means with the same letter are not significantly different. NS - Not significant. 
Observations were also made on dry matter partitioning. At physiological maturity, total dry matter was partitioned into leaf, stem and grain. Significantly higher stem, leaf and grain partitioning was found with 5 seedlings hill-1 $\left(\mathrm{S}_{3}\right)$ and was significantly superior to 3 seedlings hill ${ }^{-1}\left(\mathrm{~S}_{2}\right)$ and 1seedling hill ${ }^{-1}\left(\mathrm{~S}_{1}\right)$, in turn $\mathrm{S}_{1}$ recorded the lowest stem, leaf and grain partitioning. The dry matter partitioning to grain at physiological maturity was in the range of $58.1 \%$ to $58.4 \%$ with different plant densities. Among all the combinations, the highest category wise stem, leaf and grain partitioning was obtained in 25 days old seedlings $\left(D_{2}\right)$ and was significantly superior to $15\left(\mathrm{D}_{1}\right), 35\left(\mathrm{D}_{3}\right)$ and 45 days old seedlings $\left(\mathrm{D}_{4}\right)$, in turn $\mathrm{D}_{4}$ recorded the lowest stem, leaf and grain partitioning. The dry matter partitioning to grain at physiological maturity was in the range of $53.9 \%$ to $59.6 \%$ with different age of seedlings (Table 2).

Plant densities and age of seedlings exerted significant influence on panicle bearing tillers. Significant decrease in panicles $\mathrm{m}^{-2}$ was observed, when the plant densities increased from 1 to 5 seedlings hill $^{-1}$. The highest number of panicles was noticed at 5 seedling hill-1 $\left(\mathrm{S}_{3}\right)$ and it was superior to 3 seedlings $\operatorname{hill}^{-1}\left(\mathrm{~S}_{2}\right)$ and 1 seedlings hill ${ }^{-1}\left(\mathrm{~S}_{1}\right)$, in turn $\mathrm{S}_{3}$ recorded the lowest panicle weight. This increased number of panicles might be due to better utilization of growth resources (Singh and Singh, 2009) and higher tiller production per unit area (Miller et al., 1991).

Table 2. Dry matter $\left(\mathrm{g} \mathrm{m}^{-2}\right)$ partitioning at maturity stage of rice under varied plant densities and age of seedlings.

\begin{tabular}{|c|c|c|c|c|}
\hline Treatments & Stem & Leaf & Grain & Total dry matter \\
\hline \multicolumn{5}{|l|}{ Plant densities (S) } \\
\hline$S_{1}\left(1\right.$ seedling hilll $\left.{ }^{-1}\right)$ & $265^{\mathrm{c}}$ & $224^{\mathrm{c}}$ & $688^{\mathrm{c}}$ & $1177^{\mathrm{c}}$ \\
\hline $\mathrm{S}_{2}\left(3\right.$ seedlings hill $\left.{ }^{-1}\right)$ & $278^{\mathrm{b}}$ & $233^{\mathrm{b}}$ & $720^{\mathrm{b}}$ & $1231^{\mathrm{b}}$ \\
\hline $\mathrm{S}_{3}\left(5\right.$ seedlings hill $\left.{ }^{-1}\right)$ & $300^{\mathrm{a}}$ & $242^{\mathrm{a}}$ & $754^{\mathrm{a}}$ & $1296^{\mathrm{a}}$ \\
\hline SEm \pm & 4.0 & 2.5 & 10.5 & 17.3 \\
\hline $\mathrm{CD}(\mathrm{p}=0.05)$ & 11.9 & 7.6 & 30.9 & 50.9 \\
\hline \multicolumn{5}{|l|}{ Age of seedlings (D) } \\
\hline $\mathrm{D}_{1}$ (15 days old seedlings) & $296^{\mathrm{b}}$ & $238^{\mathrm{b}}$ & $787^{\mathrm{b}}$ & $1321^{\mathrm{b}}$ \\
\hline $\mathrm{D}_{2}$ (25 days old seedlings) & $330^{\mathrm{a}}$ & $261^{\mathrm{a}}$ & $824^{\mathrm{a}}$ & $1415^{\mathrm{a}}$ \\
\hline $\mathrm{D}_{3}$ (35 days old seedlings) & $260^{c}$ & $224^{\mathrm{c}}$ & $746^{\mathrm{c}}$ & $1230^{c}$ \\
\hline $\mathrm{D}_{4}$ (45 days old seedlings) & $239^{\mathrm{d}}$ & $210^{\mathrm{d}}$ & $525^{\mathrm{d}}$ & $974^{\mathrm{d}}$ \\
\hline SEm \pm & 4.6 & 3.0 & 12.2 & 20.0 \\
\hline $\mathrm{CD}(p=0.05)$ & 13.7 & 8.8 & 35.7 & 58.7 \\
\hline \multicolumn{5}{|l|}{ Interaction (S X D) } \\
\hline $\mathrm{SEm} \pm$ & 8.1 & 5.1 & 21.0 & 34.7 \\
\hline $\mathrm{CD}(p=0.05)$ & NS & NS & NS & NS \\
\hline
\end{tabular}

Note: Means with the same letter are not significantly different. NS - Not significant.

Significantly, the highest panicles $\mathrm{m}^{-2}$ was obtained with 25 days old seedlings $\left(D_{2}\right)$ and was on par with 15 days old seedlings $\left(\mathrm{D}_{1}\right)$, while these two were superior over 35 days old seedlings $\left(D_{3}\right)$ and 45 days old seedlings $\left(D_{4}\right)$ as they recorded the lowest panicle number. Plant density and age of seedlings were found to influence grain yield significantly.

Data on grain yield of rice revealed that, higher grain yield was obtained from 5 seedlings $\operatorname{hill}^{-1}\left(\mathrm{~S}_{3}\right)$ and was significantly superior to 3 seedlings $\operatorname{hill}^{-1}\left(S_{2}\right)$ and 1 seedling hill' ${ }^{-1}\left(\mathrm{~S}_{1}\right)$, in turn $\mathrm{S}_{1}$ recorded the lowest grain yield (Table 3). This result is in agreement with the research results of Hasan et al. (2005) who reported the highest grain yield from 6 seedlings hill $^{-1}$ and lowest grain yield from 2 seedlings hill ${ }^{-1}$.

The per cent increase in grain yield with 5 seedlings hill ${ }^{-1}$ over $1\left(\mathrm{~S}_{1}\right)$ and $3\left(\mathrm{~S}_{2}\right)$ seedlings hill $^{-1}$ was $12.3 \%$ and $5.6 \%$, respectively. The increased grain yield of rice might be due to higher plant population, more leaf area index, more light interception and more number of effective tillers $\mathrm{m}^{-2}$ resulting in yield enhancement in 5 seedlings hill ${ }^{-1}$ (Rasool et al., 2012).

The grain yield of rice was declined with age of seedlings due to reduced dry matter accumulation and 
productive tillers. The highest grain yield was noticed in 25 days old seedlings $\left(\mathrm{D}_{2}\right)$, which was significantly superior to $15\left(\mathrm{D}_{1}\right), 35\left(\mathrm{D}_{3}\right)$ and 45 days old seedlings $\left(\mathrm{D}_{4}\right)$. In turn the lowest grain yield was recorded from $\mathrm{D}_{4}$.
The per cent increase in grain yield with 25 days old seedlings $\left(\mathrm{D}_{2}\right)$ over $15\left(\mathrm{D}_{1}\right), 35\left(\mathrm{D}_{3}\right)$ and 45 days old seedlings $\left(\mathrm{D}_{4}\right)$ was $8.6 \%, 15.9 \%$ and $84.9 \%$, respectively.

Table 3. Grain yield and of rice under varied plant densities and age of seedlings.

\begin{tabular}{lll}
\hline Treatments & Panicles $\mathbf{~ m}^{-2}$ & ${\text { Grain yield }\left(\mathbf{k g ~ h a}^{-\mathbf{1}}\right)}$ \\
\hline Plant densities (S) & & \\
1 seedling hill & $249^{\mathrm{c}}$ & $5134^{\mathrm{c}}$ \\
3 seedlings hill & $266^{\mathrm{b}}$ & $5457^{\mathrm{b}}$ \\
5 seedlings hill & $288^{\mathrm{a}}$ & $5817^{\mathrm{a}}$ \\
SEm \pm & 3.0 & 95.4 \\
CD $(p=0.05)$ & 7.9 & 279.8 \\
Age of seedlings (D) & & \\
15 days old seedlings & $284^{\mathrm{b}}$ & $6060^{\mathrm{b}}$ \\
25 days old seedlings & $296^{\mathrm{a}}$ & $6583^{\mathrm{a}}$ \\
35 days old seedlings & $251^{\mathrm{c}}$ & $5676^{\mathrm{c}}$ \\
45 days old seedlings & $240^{\mathrm{d}}$ & $3559^{\mathrm{d}}$ \\
SEm \pm & 3.0 & 110.1 \\
CD $(p=0.05)$ & 9.0 & 323.1 \\
Interaction (S X D) & & \\
SEm \pm & 5.4 & 190.8 \\
CD $(p=0.05)$ & $\mathrm{NS}$ & $\mathrm{NS}$ \\
\hline
\end{tabular}

Note: Means with the same letter are not significantly different. NS - Not significant.

The higher grain yield production in the younger seedlings of 25 days might be attributed to the vigorous and healthy growth, development of more productive tillers and leaves ensuring greater resource utilization as compared to old age seedlings (Pramanik and Bera, 2013). The younger seedlings also aid to better phyllochron development and better tillering and thus, increase the final grain yield (Datta, 1980).

Even though on par results observed in terms of panicle length, panicle weight, total spikelets per panicle and filled spikelets per panicle, the reduced yield in 15 days old seedlings over 25 days old seedlings was due to lesser effective tillers $\mathrm{m}^{-2}$. This might be due to the mortality of young (15 days old) seedlings right after transplanting was reported as a reason for the lower yield compared to 25 days old seedlings (Bagheri et al., 2011).

Optimum plant density for higher DMP and grain yield would be 5 seedlings hill ${ }^{-1}$ and 25 days old seedlings produced higher DM and grain yield with highest partitioning towards panicle followed by stem and leaf.

\section{Conflict of interest statement}

Authors declare that they have no conflict of interest.

\section{References}

Bagheri, R., Mobasser., H.R.. Ghanbari-Malidarreh, A., Dastan, S., 2011. Effect of seedling age and potassium rates on morphological traits related-lodging, yield and yield components of rice (Oryza sativa L.) in Iran. Amer.Eur. J. Agric. Environ. Sci. 11(2), 261-268.

Damodaran, V., Saren, B.K., Ravisankar, N., Bommayasamy, N., 2012. Influence of time of planting, spacing, seedling number and nitrogen management practices on productivity, profitability and energetic of rice in Island ecosystem. Madras Agric. J. 99(7-9), 538-544.

Datta, S.K.D., 1980. Principles and Practices of Rice Production. Wiley \& Sons, Singapore.

Hasan, A. K., Anwar, M. P., Rashid, M. H., 2005. Response of late transplant $\mathrm{cv}$. BR23 to planting geometry and number of seedlings hill ${ }^{-1}$. Bangl. J. Crop Sci. 16(1), 123-127.

Jeng, T.L., Tseng., T.H., Wang, C.S., Chen, C.L., Sung, J.M., 2006. Yield and grain uniformity in contrasting rice genotypes suitable for different growth environments. Field Crops Res. 99(2006), 59-66.

Miller, B. C., Hill, J. E., Roberts S. R., 1991. Plant population effects on growth and yield in water-seeded rice. Agron. J. 83, 291-297.

Pramanik, K., Bera, A. K., 2013. Effect of seedling age and nitrogen fertilizer on growth, chlorophyll content, yield and economics of hybrid rice (Oryza sativa L.). Int. J. Agron. Plant Prod. 4, 3489-3499. 
Rasool, F.Ur., Habib, R., Bhat, M.I., 2012. Evaluation of plant spacing and seedlings hill $^{-1}$ on rice (Oryza sativa L.) productivity under temperate conditions. Pak. J. Agric. Sci. 49(2), 169-172.

Rice Knowledge Management Portal (RKMP), 2013. Directorate of Rice Research, Rajendranagar, Hyderabad. http://www.rkmp.co.in

Singh, A. K., Singh, G. R., 2005. Effect of seedling density and planting geometry on hybrid rice. Oryza. 42(4), 327328.
Thiyagarajan, T. M., Velu, V., Ramasamy, S., Durgadevi, D., Govindarajan, K., Nisha, P.T., Gayathry, G., Hengsdijk, H., Bindraban, P.S., 2002. System of rice intensification: Evaluation of seedling age and selected components in Indonesia. In: Proc. Int. Workshop on Water-Wise Rice Production (Eds.: Bouman, B.A.M., Hengsdijk, H., Hardy, B., Bindraban, P.S., Tuong, T.P., Ladha, J.K.). IRRI, Philippines. pp.119-127.

\section{How to cite this article:}

Vijayalaxmi, G., Sreenivas, G., Leela Rani, P., Ram Prakash, T., 2016. Influence of plant densities and age of seedlings on dry matter partitioning and grain yield potential of transplanted rice (Oryza sativa L.). Int. J. Curr. Res. Biosci. Plant Biol. 3(4), 51-55.

doi: http://dx.doi.org/10.20546/ijcrbp.2016.304.009 